DOI 10.14746/ssp.2018.3.9

Magdalena LORENC

Adam Mickiewicz University in Poznań

Michał MiкоŁAJCZAK

Nicolaus Copernicus University in Toruń

\title{
Liturgical references in the swearing-in ceremonies of the President of the Republic of Poland after 1989
}

\begin{abstract}
"Rational thought could not create rituals whose seriousness could be comparable to the seriousness of rituals associated with beliefs that have lost their credibility."

Edward Shils, Ritual and Crisis, London, p. 449.
\end{abstract}

\begin{abstract}
The text analyzes the mutual relations between the liturgy of sacraments and the most solemn state ceremony in the Republic of Poland, that of swearing-in of the Head of State. Although the latter ceremony is secular, its antecedence should be sought in the religious aspects of the enthronement of European rulers in the Middle Ages. These references make the swearing-in an object of study combining theology and political science. They invite questions about the relation between the religious imagination of a given national community and its political organization as embodied in state ceremonies. The candidate who wins the presidential elections becomes the President of the Polish Republic after their victory is announced by the National Electoral Commission, and after the Supreme Court confirms validity of this result. However, they remain President-Elect until they utter the words of the oath. Therefore, the swearing-in is a public ritual regulated by law which needs to be completed in order to formally commence exercise of the office. The oath, which is spelled out in the Constitution and delivered by the newly elected Head of State, has a performative nature, similar to liturgical formulas. Additionally, it comprises an optional reference to God as witness to the oath delivered. Therefore, the presidential oath is a historically conditioned testimony to public authority, referring to the realm of the sacred.
\end{abstract}

Key words: ceremony, swearing in of the Head of State, liturgy, ritual

\section{Introduction}

7 he theatricalization of political life is a universal phenomenon. It involves attributing the features of a spectacle to the public practices 
of power, which can be exemplified by state ceremonies. They take place in a specific setting, according to a set scenario and with precise roles. The most important celebration of this type in Poland is the inauguration of the President, which consists of the following ceremonies: the swearing-in, transfer of presidential insignia, taking over the authorities over the armed forces and the official welcome to the presidential residence. They are regulated by both law and custom. Particularly important during the inauguration is the swearing-in, the oath of which was enacted in the Constitution of the Republic of Poland of April 2, 1997. Uttering this oath before the combined chambers of the Sejm and the Senate is a prerequisite, and the initial turning-point as the newly elected head of state begins to carry out their duties. This distinguishes the swearing-in from other inaugural ceremonies. The uniqueness of this ceremony also results from references to Christian religious practices, making it the subject of research of both theology and political science. In it, the liturgy of the sacraments of the Catholic Church is echoed, understood as the order of worship which consists of specific words, gestures and context.

The aim of the current paper is to analyze the mutual ties between the liturgy of the sacraments, for example of the rite of baptism, and the most important state ceremony of the Third Republic. The basic research questions concern the sources and significance of liturgical references of the swearing-in ceremony of Polish presidents elected after 1989, including Lech Wałęsa (December 22, 1990), Aleksander Kwaśniewski (December 23, 1995, December 23, 2000), Lech Kaczyński (December 23, 2005), Bronisław Komorowski (August 6, 2010) and Andrzej Duda (August 6, 2015).

For the elaboration on the subject, historical and legal analyses by Grzegorz Maron were particularly helpful, as they discussed the significance of the head of state's oath in Polish fundamental acts of law. In addition, Arnold van Gennep's concepts of rites of passage and John Langshaw Austin's notions of performatives were used. While the former served to show the differences between the liturgy and the swearing-in, the latter made it possible to find an analogy between them. In the case of baptism, there are three stages of change in the status of the person undergoing the ritual, which cannot be demonstrated in the swearing-in ceremony. At the same time, the trinitarian formula and the wording of the oath, fulfilling the conditions necessary for a successful performative, bear performative value - purify from sin (baptism), and elect the president (swearing-in). 


\section{Theological understanding of liturgy}

The word liturgy is of Greek provenance. Formed by connecting $\lambda \alpha o ́ \varsigma$ (people) and है $\rho \gamma o v-($ deed $)-\lambda \varepsilon \imath \tau o v \rho \gamma \iota \alpha^{1}$ originally meant any public activity, including organization of games and festivals, sending legates or launching ships (Nadolski, 1989, p. 9). The understanding of the liturgy, adopted from Greek, was narrowed down in ancient Rome to cult activities associated with worshipping gods. In the Bible, liturgy as a derivative of the Greek root, and the Hebrew forms (sheret and aboad) was applied to Tanakh rituals. ${ }^{2}$ The Latin term liturgica was used for the first time by Georg Cassander in 1558 (Nadolski, 1989, p. 1). At that time, it concerned only the Holy Mass, while with time it would be extended to all the celebrated mysteries.

Nowadays, the term liturgy is understood in the Catholic Church as the entire public worship directed to God and anamnetic in nature. This means that the events remembered during the liturgy 'make themselves present;' that is, they are treated by believers as currently happening. Such was the position of the Second Vatican Pastoral Council of December 4, 1963 expressed in the Constitution on the Sacred Liturgy (CL), according to which the liturgy is regarded as "an exercise of the priestly office of Jesus Christ. In it, visible signs are expressed and in a manner appropriate for particular signs, the sanctification of man takes place, and the Mystical Body of Jesus Christ, that is, the Head with its members, exercises full public worship. From this it follows that every liturgical celebration, because it is an action of Christ the priest and of His Body which is the Church, is a sacred action surpassing all others; no other action of the Church can equal its efficacy by the same title and to the same degree" (CL, point 7).

Antecedents of liturgical practices can be mainly found in classical theater and court ceremonies (Paprocki, 2007). Using the knowledge of Greek theater, the early-medieval Christian communities performed short plays, the subject of which were the events described in the Bible. This

${ }^{1}$ Cf. the leiturgia entry in: Stownik grecko-polski, ed. by O. Jurewicz, Warszawa 2015, p. 578; also, liturgia in: Mała encyklopedia kultury antycznej, ed. by Z. Piszczek, Warszawa 1988, p. 424.

2 In the Bible, the term liturgy is used to refer to tax collectors, persons providing material help and organizing the collection of gifts for poor Christians (see, e.g., Romans 13:26). The liturgy also refers to the public spiritual worship in the New Testament (see, e.g., Hebrews 8:2-6). 
was to facilitate the mission of evangelization and to serve didactic purposes, just as later Bibliae pauperum. A separate practice derived from the theater was the liturgical drama which assisted the Church up to the Council of Trent (1545-1563). This concept was understood as all activities that had the features of a stage work and were subordinated to the liturgy (cf. Wolański, 2005, pp. 7-8). When writing drama scripts, authors used the Bible, homilies, legends, apocrypha, responsories and other sources. The actors were mostly priests, with clerics or monks, and the liturgical dramas were adapted to the calendar of religious holidays. For example, performances related to the passion and death of Jesus Christ were performed in Lent, especially during the Holy Week. In this way, "the church adopted the theater, offering it its biblical content, philosophy, mysticism, props, interior, word and music. The theater enriched the liturgical rite with spectacularity, drama and beauty" (Towarek, 2008, p. 111).

The court ceremonial, both in its expanded Byzantine version and the more modest Roman one, provided the patterns of behavior in the presence of the ruler which per analogiam would be useful during the Eucharist celebrated in persona Christi. This influence was visible especially in the liturgy with the participation of the Pope, who until Vatican II was dressed in a special outfit, shoes and gloves, and wore a tiara on his head. He did not move independently but was brought to Saint Peter's Basilica in a litter, with the sound of trumpets, "among feather fans and a large, colorful group of lay people and prelates... and representatives of nobility and Roman patricians, various guard corps and other dignitaries of the papal court. This was about a ceremonial entrance which gave the pope the appearance of the prince of this world surrounded by his own court" (Marini, 2007, p. 76).

Meanwhile, the first half of the twentieth century, with the tragedy of two world wars and the beginning of the cold-war rivalry between the East and the West, led to social and cultural changes, the consequences of which the Church was not spared. Their manifestation was dynamically developing ecclesiological thought which influenced, among others, a new perception of the liturgy. The encyclical Mediator Dei et Hominum of November 20,1947, by Pius XII, together with a grassroots movement for the renewal of the liturgy, was an important voice on the road to its simplification which was reflected in the documents of the Second Vatican Council. It was decided then that " $[\mathrm{t}]$ he rite of the Mass is to be revised in such a way that the intrinsic nature and purpose of its several parts, as also the connection between them, may be more clearly manifested, and 
that devout and active participation by the faithful may be more easily achieved. For this purpose, the rites are to be simplified, due care being taken to preserve their substance; elements which, with the passage of time, came to be duplicated, or were added with but little advantage, are now to be discarded" (CL, point 50).

The "simplification" of the liturgy concerned not only the Eucharist, but also other sacraments which "[...] are efficacious signs of grace, instituted by Christ and entrusted to the Church [...]. The visible rites by which the sacraments are celebrated signify and make present the graces proper to each sacrament. They bear fruit in those who receive them with the required dispositions" (CCC 1131). There are seven of them: Baptism, Confirmation, Eucharist, Penance, Anointing of the Sick, Holy Orders, and Matrimony.

The definition contained in the Catechism indicates the special role of the sacraments in the liturgical life of the Catholic community. In the opinion of believers, when sacraments are granted, the receiver changes their status. An example of this is the baptism, which means incorporation into the community through purification of sins. Its validity requires pronouncing the baptismal formula: "... (name), I baptize you in the name of the Father, and of the Son, and of the Holy Spirit." These words are a quote from the Gospel of Matthew, according to which Christ commanded his disciples to go and teach all nations, "baptizing them in the name of the Father, and of the Son, and of the Holy Spirit" (Mt 28:19). Recalling the Trinity in the trinitarian formula means its presence and uniting the baptized person with it. For the efficacy of the sacrament, it is also necessary to use clean water in a gesture of washing the body or its part (the head). Both activities are the focal point of the celebration of the sacrament of Baptism. Limiting the ritual to them alone is, however, rare and concerns special circumstances, for instance when the life of the baptized person is threatened. In other cases, the rite of the sacrament is more elaborate. Because children are most often baptized, their parents or guardians make the decision, bring the child to church and express - on their behalf - the wish for baptism. A steward, who is the person entitled to administer a sacrament, introduces the parents or guardians together with the child to the church. Next, an exorcism is pronounced over the child, accompanied by the steward's gesture of the hand. In this way, they ask for release from the power of sin and for the grace of living with Jesus Christ. Another element of the liturgy of the baptismal sacrament is the profession of faith and the obligation of parents or guardians to 
raise the child in the faith of the Catholic Church. After the confession of faith comes the moment of proper baptism, that is the utterance of the trinitarian formula and pouring of water on the head. It symbolizes the inclusion of a new member into the Catholic (and more broadly, Christian) community. The subsequent rites are 'explanatory' and include: anointing with consecrated oils - consisting in making the sign of the cross with a finger immersed in a mixture of balm and oil, putting on white garments and lighting a candle. During each of these activities, the steward prays aloud, which makes it possible to understand the meaning of individual gestures. The anointing with the oils is evidence of purification from sin. Putting on a white gown proves the state of cleanliness, while lighting of the candle from the paschal candle symbolizes receiving light from Christ. An indispensable part of the ritual is the participation of one or two godparents, and optionally also a witness or witnesses to the baptism, who do not replace the godparent (cf. Code of Canon Law, 874 § 2). The baptized person is treated as newborn, and not burdened with sin. Baptism is, therefore, an example of a rite of passage. According to the concept of Arnold van Gennep, it involves a change in the status of the person concerned (Gennep, 2006, p. 37). The passage has three stages: preliminal (separation), liminal (transitional) and post-liminal (incorporation) (Gennep, 2006, p. 45). ${ }^{3}$ Observance of the order of the ritual, including the formulas used, utensils and division of roles, reduces the anxiety accompanying the change and constitutes the conditions for the effectiveness of the ritual. Its phatic power consists in transforming reality, and not only in registering or confirming change.

The celebration of the liturgy of the sacraments was and still is a model for other public celebrations, including state ceremonies. As Ernst Wolfgang Böckenförde pointed out, "for thousands of years, thinking and theories of the political order in society have been associated with religious imaginations, and in Christian times - also theological ones" (Böckenförde, 2005-2006, p. 301). The manifestation of the fact that "Christianity has left an indelible mark on the European culture" (Gołembski, 2008, p. 199) and significantly influenced the formation of symbolic space (of which culture and especially political culture is a part $\left.{ }^{4}\right)$, are state ceremo-

${ }^{3}$ More on this topic also in: E. Leach, A. J. Greimas, Rytuat i narracja, Warszawa 1989 and V. W. Turner, Proces rytualny. Struktura i antystruktura, Warszawa 2010.

${ }^{4}$ More on the relationship between the symbolic space and culture in the context of Christian roots in Europe can be found in: M. Gierycz, Chrześcijaństwo i Unia Europejska. Rola religii w procesie integracji europejskiej, Warszawa-Kraków 2008; 
nies. The genesis of religious inspirations of state ceremonies is the aftermath of the Middle Ages, when politics was "one of the forms of religious communities' activity in achieving their goals, and the distinction between secular and religious authority did not exist" (Gierycz, 2008, p. 26).

\section{The most important state ceremony}

The swearing-in of the newly elected head of state is part of the inauguration of the presidency, and the most important state ceremony in Poland. It consists in saying the words of the oath, in accordance with the pattern set out by law, before the relevant auditorium. Among the highest representatives of state power, apart from the President, an oath is taken by the President, Vice-President, and Members of the Council of Ministers. However, because the mandate of the head of state comes from general elections, it makes it stronger than the other organs of the executive, including prime ministers and ministers. ${ }^{5}$

The legal basis for the political position of the president is the Constitution of the Republic of Poland of April 2, 1997, according to which he or she takes office after uttering before the National Assembly an oath with the following wording: "By taking the office of the President of the Republic of Poland by the will of the Nation, I solemnly swear that I will be faithful to the provisions of the Constitution, I will steadfastly protect the dignity of the Nation, independence and security of the State, and the well-being of my citizens will always be the highest command for me." The oath may finish with the phrase "So help me God" (Article 130).

Over the 25 years between the inaugurations of Presidents Wałesa in 1990 and Duda in 2015, the text of the written and spoken oath has slightly evolved. The basic difference concerned the constitution, which

F. Gołembski, Cywilizacja europejska, Warszawa 2012; idem, Jedność europejska, Warszawa 2006; J. Kłoczkowski, Europa - chrześcijańskie korzenie, Warszawa 2004.

${ }_{5}$ More on this topic also in: D. Górecki, Wptyw polskich tradycji ustrojowych na współczesne rozwiqzania konstytucyjne, in: Konstytucyjne systemy rzadów, ed. M. Domagała, Warszawa 1997; R. Mojak, Instytucja Prezydenta RP w świetle nowej Konstytucji, "Państwo i Prawo" 1997, 11-12; R. Mojak, Pozycja ustrojowa i struktura władzy wykonawczej. Problematyka stosunków między prezydentem a rzadem, in: Ustrój i struktura aparatu państwowego i samorzqdu terytorialnego, ed. W. Skrzydło, Warszawa 1997; R. Mojak, Władza wykonawcza w Konstytucji RP, in: Ustrój konstytucyjny Rzeczypospolitej Polskiej, Wyd. UMCS, Lublin 2000. 
the new president swore to be faithful to, and the appeal to God as a help in fulfilling the obligation. Lech Wałęsa swore on the Constitution of the Republic of Poland, being the amended Constitution of the Polish People's Republic of July 22, 1952. During his first inauguration, Aleksander Kwaśniewski swore on the Constitutional Act of October 17, 1992 on the mutual relations between the legislative and executive power of the Republic of Poland and local government (the so-called Small Constitution). His second oath, as well as the ceremonies of successive presidents: Kaczyński, Komorowski and Duda, included swearing on the Constitution of the Republic of Poland of April 2, 1997.

The oath pronounced by the first President of the Third Republic ${ }^{6}$ elected in equal, free and universal elections, read: "Embracing the office of the President of the Republic of Poland, I swear solemnly to the Polish Nation that I will be true to the provisions of the Constitution, and I will steadfastly guard the dignity of the Nation, the sovereignty and security of the state. I vow that the good of the Homeland and the well-being of citizens will always be the highest command for me" (Art. 32(c)). The oath of Lech Wałęsa was introduced by the Act of April 7, 1989 on the amendment of the Constitution of the Polish People's Republic, and took into account subsequent amendments, including: the Act of December 29, 1989 on the change of the Constitution of the Polish People's Republic, in which the name of the state, "Polish People's Republic," was amended to "Republic of Poland," as well as the Act of September 27, 1990 on the election of the President of the Republic of Poland, under which the election of the head of state was no longer done by the National Assembly.

When uttering the oath, at the end Lech Wałęsa added "So help me God." This was a deviation from the formula required by law, and at the same time a reference to the tradition of the Second Polish Republic. Specifically, according to the Constitution of March 17, 1921, the words of the oath were: "I swear to the Almighty God, One in the Holy Trinity, and I vow to you, the Polish nation, in the office of the Presi-

${ }^{6}$ Lech Wałessa assumed the office of the President of the Republic of Poland after Wojciech Jaruzelski who had been elected by the National Assembly under the amended Constitution of the Polish People's Republic and sworn in as President of the Polish People's Republic on July 19, 1989. On December 31, 1989, with the entry into force of the regulation introducing a new nomenclature of state offices, the office he held was renamed as President of the Republic of Poland. This office was held by Jaruzelski until the end of the term of office, namely until December 22, 1990 when the oath was taken by the president elected in the general election. 
dent of the Republic which I am assuming: the rights of the Republic and, above all, the Constitutional Law, to honor and defend; the universal good of the Nation to serve faithfully with all my strength; all evil and danger from you, to turn away watchfully; the dignity of the Polish name to protect unwaveringly; justice for all without distinction to have as the first virtue; and to sacrifice to the duties of office and service. So help me God and the Holy Passion of His Son. Amen [emphasis - ML]" (Article 54).

A similar solution was applied in the Constitution of April 23, 1935, which featured the following oath: "Aware of the responsibility towards G o d and history for the fate of the State, I swear to the Almighty God, One in the Holy Trinity, at the office of the President of the Republic to protect State sovereignty, protect State dignity, apply the constitutional law, be guided by justice towards all citizens, avert evil and danger from the State, and care for its good as my chief duty. So help me God and the Holy Passion of His Son. Amen [emphasis - ML]" (Article 19).

The pre-war oaths contained, thus, references to transcendence. Both cases, however, did not concern an abstract being, but the Christian God in his three hypostases: God the Father, the Son of God and the Holy Spirit. The legislator, taking into account the dominance of the Catholic religion among the citizens of the Second Republic, simultaneously did not take into account the possible lack of any denomination, or different faith of the president. Thus, according to the records, on December 11, 1922, the first president of free Poland Gabriel Narutowicz uttered the complete oath, regardless of his Freemason views. After the one-person institution of the head of state was restored to the Polish constitutional order, ${ }^{7}$ which took place under the Act of April 7, 1989 on the amendment of the Constitution of the Polish People's Republic, four of five presidents of the Third Republic elected in free elections before 2015 ended their oath with an appeal to God. The exception was Aleksander Kwaśniewski who during the swearing-in for his first term repeated the oath recorded

${ }^{7}$ More on this topic also in: M. Chmaj, Sejm ,kontraktowy” $w$ transformacji systemu politycznego Rzeczypospolitej Polskiej, Wyd. UMCS, Lublin 1996; P. Sarnecki, Prezydent jako organ czuwajacy nad przestrzeganiem Konstytucji, "Państwo i Prawo" 1990, 11; W. Sokolewicz, Kwietniowa zmiana Konstytucji, "Państwo i Prawo" 1989 6; W. Skrzydło, Przemiany polityczno-ustrojowe w Polsce na przełomie lat osiemdziesiatych i dziewięćdziesiatych, in: Prawo konstytucyjne, ed. W. Skrzydło, Lublin 1996. 
in the Small Constitution, as follows: "By taking the office of President of the Republic of Poland by the will of the Nation, I solemnly swear that I will be faithful to the provisions of the Constitution, I will steadfastly protect the dignity of the Nation, independence and security of the State, and that the good of the Homeland and the well-being of citizens will always be my highest command" (Article 30(1)). Therefore, he resigned from the appeal to God, foreseen as optional in this act, and did the same during his swearing-in for a second term, which took place under the conditions of the Constitution of 1997, which also provided for voluntariness in this respect.

The swearing-in ceremonies of presidents Kaczyński, Komorowski and Duda, did not differ in formal terms and had as their basis the same wording of the oath, in each case with the added appeal to God. However, the ceremony was not free from errors. Bronisław Komorowski used the word "dobrość" instead of "dobro," i.e. "goodness" instead of "good," which aroused the doubts of some of his opponents. They accused the newly elected president of not fulfilling the obligation to take the oath in accordance with the constitutional model, and that consequently he had no right to perform his function. To support this argument, the example of Barack Obama was quoted, when he confused the order of the words of the oath during his swearing-in ceremony as $44^{\text {th }}$ President of the United States, on January 20, 2009. It was due to a mistake by the President of the Supreme Court, John Roberts, after whom the President repeated the words. In this situation it was decided the oath would be taken once again, although at the same time the validity of the first ceremony was emphasized. Unlike the American President, however, Bolesław Komorowski decided not to repeat the oath.

Pursuant to the Act of January 5, 2011 (Election Code), the result of the presidential election is stated by the National Electoral Commission (NEC) by way of a resolution which is forwarded immediately to the Speaker of the Sejm, the acting president and newly elected head of state (Article 317). The Commission's announcement is subject to publication in the Journal of Laws. From the moment the presidential election results are made public, it is possible to submit an electoral protest before the Supreme Court (SC) within 14 days. The Court ultimately decides on the validity of the election and adopts a resolution in this matter within 30 days. It is presented promptly to the Speaker of the Sejm, sent to the National Electoral Commission and announced in the Journal of Laws. At the same time, neither the Constitution currently in force nor the Elec- 
tion Code, specify the number of days from the moment the resolution is passed by the Supreme Court until the day the oath is taken. This is not exceptional; starting from 1990 the date of taking office of the President of the Republic of Poland was more often dictated by custom than by statutory regulations. However, it should not be understood that the law did not stipulate the initial and final day of the term of the president, but only that in most legal acts the number of days between the date of the resolution of the Supreme Court and the date of the swearing-in was not specified.

Table 1

The dates of the announcement of the presidential election results by the National Electoral Commission (NEC), the issuance of a resolution confirming the validity of elections by the Supreme Court (SN) and the swearing-in of the newly elected head of state, after 1989

\begin{tabular}{||l|l|l|l||}
\hline \multicolumn{1}{|c|}{ President } & $\begin{array}{l}\text { The date of the an- } \\
\text { nouncement of the } \\
\text { result by NEC }\end{array}$ & $\begin{array}{c}\text { The date of the resolu- } \\
\text { tion issued by the SC }\end{array}$ & \multicolumn{1}{|c||}{$\begin{array}{c}\text { The date of the } \\
\text { swearing-in }\end{array}$} \\
\hline Lech Wałęsa & December 10,1990 & $\begin{array}{l}\text { December 22, 1990 (va- } \\
\text { lidity declared by the Na- } \\
\text { tional Assembly) }\end{array}$ & December 22, 1990 \\
\hline $\begin{array}{l}\text { Aleksander } \\
\text { Kwaśniewski } \\
\text { (first term) }\end{array}$ & November 20,1995 & December 9, 1995 & December 23, 1995 \\
\hline $\begin{array}{l}\text { Aleksander } \\
\text { Kwaśniewski } \\
\text { (second term) }\end{array}$ & October 9,2000 & November 6, 2000 & December 23, 2000 \\
\hline Lech Kaczyński & October 24, 2005 & November 23, 2005 & December 23, 2005 \\
\hline $\begin{array}{l}\text { Bronisław } \\
\text { Komorowski }\end{array}$ & July 5, 2010 & August 3, 2010 & August 6, 2010 \\
\hline Andrzej Duda & May 25, 2015 & June 23, 2015 & August 6, 2015 \\
\hline
\end{tabular}

Source: Own work [M.L.].

Lech Wałesa took the oath on the last day of office of the outgoing head of state, within 7 days from the day on which the election was confirmed. Meanwhile, Aleksander Kwaśniewski, taking the office of President for the first time, took the oath the day after the expiration of the predecessor's term; the only time such a situation occurred in the Third Republic. Another set of exceptional circumstances characterized the inauguration of Bronisław Komorowski, who took office as a result of accelerated elections after the death of Lech Kaczyński in the plane crash 
of April 10, 2010. In his case, the period from the confirmation of the validity of the election by the NEC to the moment of the swearing-in was the shortest, and amounted to three days. The remaining presidents participated in the ceremony on the day the predecessors' office ended. Aleksander Kwaśniewski waited the longest for the swearing-in ceremony (of his second term, as in the case of the first it was only two weeks). Similarly to Andrzej Duda, he took the oath after approximately a month and a half. Lech Kaczyński was sworn in a month after the validity of the election was confirmed.

Taking of the oath is a prerequisite for taking office, and also marks the beginning of the new president's term of office and the end of the predecessor's office. The ceremony takes place in the Sejm. The invited guests are, among others, the outgoing President and their spouse, the acting Prime Minister and ministers, representatives of the most important institutions, former Speakers of Parliament and Prime Ministers, members of the Diplomatic Corps, representatives of churches and religious associations, and journalists. The heads of the Chancellery of the Sejm and Senate as well as the Speakers of the Sejm and the Senate welcome the President-Elect and their spouse to the Sejm.

The session starts in the morning hours, usually at 10:00 am. The sessions of the combined chambers of the Sejm and the Senate are chaired by the Speaker of the Sejm, while additional services are provided by the Chancellery of the Sejm. The Speaker of the Sejm heads at the presidium table and has the Speaker of the Senate to the left. The guests stand up, while the newly elected head of state enters in the company of their closest family members and co-workers. The Speaker opens the proceedings and strikes three times with the Speaker's staff, and then welcomes both the newly elected and the resigning president together with their accompanying persons, as well as guests and members of the Assembly. The Speaker appoints two secretaries - a senator and an MP and indicates the MP as the clerk. Further, the Speaker of the Sejm turns to the newly elected president with a request to take the oath. The presidential couple approaches the presidential table, and the Speaker asks the President to repeat the oath after them. Afterwards, the Speaker of the Sejm declares that the President has uttered the oath prescribed by law before the National Assembly, after which the Polish anthem is played. Following that, the Speaker congratulates the President on their election, wishes them good luck and asks them to speak. The President makes an address, while the guests are sitting. When they finish their speech, the Speaker of the 
Sejm asks the secretary who has been recording the session to read the minutes out and then asks the members of the Assembly if there are any objections to the minutes. In the absence of objections, they announce the acceptance of the minutes and close the debate by striking three times with the Speaker's staff. After approximately 30 minutes, the ceremony comes to an end.

After leaving the session chamber, it is time for farewells to the outgoing head of state, visiting the parliamentary cabinet and the meeting of the President with the conventions of seniors of the Sejm and the Senate. These elements are of courteous character and depend on the individual preferences of the new head of state, as well as on the circumstances.

Due to the lack of clearly distinguished stages of separation, liminality and incorporation, the swearing-in ceremony does not meet Gennep's criteria for a rite of passage. This stems mainly from the inability to recognize the period of being an elect as a transient state, even though there is such a state in the colloquial sense. In cultural anthropology, however, this is not enough, because the immanent feature of the liminal phase is the suspension of the existing order, including the moral norms in force, in relation to the person subjected to the ritual. It is impossible to see this in relation to the president-elect who is elected and whose choice has been legally confirmed, but they have not yet formally taken the position. Although the custom is that they change their place of residence for the period between the announcement of election results and the swearing-in, this is not a sufficient condition to consider being elect as a liminal phase. So far, the invitation to stay at the Przeździecki Palace, also known as the Palace of the Ministry of Foreign Affairs was accepted by Aleksander Kwaśniewski, Lech Kaczyński and Andrzej Duda.

\section{Performativity of expression and divine sanction}

A ceremony is "an official celebration or ritual, running according to a set plan or ritual, [but also-ML] an act performed with seriousness and attention to preserving conventions" (Stownik). This definition is derived from colloquial language, and is far from the approach well-founded in anthropology that requires the aspect of the sacrum (Émile Durkheim); it is closer to the position of Mary Douglas, whose merit was the liberation of rituals from religious affiliation, and giving them a wider symbolic meaning. This allowed non-religious rituals, including political ones, to 
be called rituals (Churska-Nowak, 2009, p. 60; Churska-Nowak, Orylski, 2010, p. 64; Eller, 2012, p. 353; Filipowicz, 1998, p. 166). Although such an attitude limited the semantic value of the concepts of ceremony, rite and ritual, at the same time it decreased the risk of aporia resulting from the use of rigid definitions of these activities (according to Durkheim, Mauss or Hubert), none of which gained a canonical rank. The basic value of such an approach consisted in avoiding an epistemological trap as a result of choosing one narrow definition - from a number of possible ones - and treating it as a reliable criterion for the selection of social phenomena. The only ordering procedure in this regard has been and remains the use of the term liturgy in relation to religious practices, which excludes speaking of the "liturgy of the swearing-in of the President of the Republic of Poland," while using the terms ritual or ceremony in relation to the sacraments.

The central point of the swearing-in ceremony is the utterance of the oath by the president-elect. This is an analogous activity to the trinitarian formula spoked by the steward during the baptism. Both these statements are performative according to Austin, who stated that "to say something means to do something" (2013, p. 561). Here, we deal not with a simple statement on an event (observation), but rather a statement of a performative nature, creating reality. For a performative to be successful, six conditions must be met:

"(A.1) There must be a recognized conventional procedure with a certain conventional effect: this procedure must involve the expression of certain words by certain persons in certain circumstances, whereby.

(A.2) individual persons and circumstances in a given case must be appropriate for establishing a specific procedure.

(B.1) All participants must carry out the procedure both correctly and

(B.2) fully.

( $\Gamma .1)$ When, as it happens often, a given procedure is intended for use by people who have certain thoughts and feelings (or to initiate the participant's certain subsequent behavior), then the participant, and thus the person who executes a given procedure, must indeed harbor these thoughts and nurture these feelings, and the intention of the participants must be to act in a given way. In addition,

(Г.2) they are supposed to execute the deed in the future in the same way" (Austin, 2013, pp. 563-564). 
Failure to meet these conditions means that the performative violates the felicity condition or is faulty. The violation of the conditions A or B means that the intended activities are futile (fiascos), and of the conditions $\Gamma$ - that these activities are infelicitous and empty (and constitute abuse) (Kałuszyńska, p. 3). Therefore, in order for a baptism and a swearing-in to be effective, the spoken words must be consistent; in the first case, with the adopted trinitarian formula, and in the second with the oath included in the Constitution of the Republic of Poland. Only particular persons should participate in the rite. The words are accompanied by gestures. How the sign of the cross is made over the baptized person must correspond to the liturgical ritual adopted in the given church. The same applies to fingers folded in a gesture of oath and/or the hand laid on the constitution. Only if these criteria are compatible with the convention is the performative successful and triggers the effect desired by the participants.

Among the conditions of a successful performative, the intentionality of the statement is also often mentioned. This is particularly evident in the case of the presidential oath. By analogy with Austin's promise, it is right for the person who utters its words to have the will to keep it (Austin, 1993, p. 557). This stems also from the meaning of the word oath as "a solemn commitment to fulfill certain obligations, to comply with certain rules," as well as "the text of this commitment" (Stownik, 2018). ${ }^{8}$

In Polish language practice the word oath (P1. przysięga) is used interchangeably with vow (Pl. ślubowanie) (Stownik, 1984, vol. 2, pp. 1055 and vol. 3, p. 448). This raises doubts from the viewpoint of legal language, in which an oath should refer to such a vow which is of a religious nature and - for example - begins with the words "I swear to the Lord God Almighty" (Maron, 2012b, pp. 126-127). At the same time, the sacral context of the swearing-in may mean not only the spoken words, but also the form of the ceremony. An example of this was the oath of allegiance to the monarch and loyalty of the state in the times of the First Polish Republic. ${ }^{9}$ It was not uncommon to utter the oath in the kneeling position, with the cross and the Gospel laid out (Maron, 2012b, p. 127). This practice did not only apply to the highest representatives of power,

${ }^{8}$ Compare the terms przysięga and ślubowanie in: Słownik języka polskiego, ed. M. Szymczak, Warszawa 1984, vol. 2, p. 1055-1056 and vol. 3, p. 448, 127.

9 More on this topic also in: J. Pietrzak, Senat Rzeczypospolitej Polskiej. Tradycja $i$ wspótczesność XV-XXI w. Warszawa 2010; S. Ochmann-Staniszewska, Przysięga marszałka poselskiego na sejmach lat 1648-1668, "Czasopismo Prawno-Historyczne" 1995, vol. XVVII, iss. 1-2. 
but also to the deputies who swore on the Bible before going on a mission, promising to strictly follow the instructions given to them.

Most fully - due to the importance of the event - the influence of religion could be seen in the case of the coronation of kings in the time of the First Polish Republic. He swore on the Gospel and was crowned by the primates, after they accepted the oath and anointed the king with holy oils (Pietrzak, 2010, p. 37). This celebration was a portrayal of medieval political theology, according to which a European monarch was of double nature, both earthly and supernatural. One of them was mortal, as the human body of a man, while the latter immortal as an idea; this was exemplified by the cry of the French heralds: "The king is dead, long live the king." These two aspects of the monarch's nature - "the two bodies of the king" - resembled Christ per analogiam to his humanity and divinity (Kantorowicz, 1957). The medieval ruler, as a result of the anointing treated as a sacrament, was no longer an ordinary human (Baszkiewicz, 1998, p. 112). "The clericalization of power was closely related to the sacralization of political life" (Gierycz, 2008, p. 29). ${ }^{10}$ It was only progressive secularization that made the King-Christ dualism give way to the king as law, and finally the king as state, finding expression in the words attributed to Louis XIV, "L'Etat, c'est moi." This meant abandoning the "Christocentric accents of the concept of royal power," in favor of the head of a secular community - a state that, equally with the Church, "is treated as something immortal and lasting eternally" (Strzelczyk, 2007, p. XX).

After regaining independence in 1918, the words of the presidential oath recorded in both fundamental acts referred directly to Catholic dogmas. Both Gabriel Narutowicz, of no religious denomination (on December 11, 1922), and the declared Catholics Stanisław Wojciechowski (on December 20, 1922) and Ignacy Mościcki (for the first time on June 4, 1926, for the second on May 9, 1933) appealed to "God Almighty, One in the Holy Trinity." Since the utterance of the oath in accordance with the constitutional provisions was obligatory, the omission of the divine recipient of the oath would invalidate it. Thus, the legislator did not foresee the atheism, or other faith of the head of state, favoring Christians of the Catholic denomination. At the same time, in the Constitution of March 17, 1921, a distinction was made between an oath and a vow. The presidential

${ }^{10}$ More on this topic also in: Monarchia w średniowieczu, eds. J. Pysiak, A. Pieniądz-Skrzypczak, M. R. Pauk, Warszawa-Kraków 2002; P. Urbańczyk, Władza i polityka we wczesnym średniowieczu, Wrocław 2000. 
oath enshrined in it included the requirement to take an oath to God and a vow to the Polish nation. However, it is difficult to say whether this was dictated by the desire to avoid a stylistic error in the form of repetition, or whether it was semantic purism that required an oath to be associated with the sphere of sacrum. ${ }^{11}$

Oaths spoken by the highest representatives of state power in the times of the First and Second Republic contained references to God as the recipient, witness and help in the implementation of the oath. They served to authenticate the commitment and were a manifestation of religious worship. Failure to keep the oath meant perjury, and therefore the breaking of the second commandment of the Decalogue. It was an insult to God, consisting in calling him a witness to lies, and included - on the basis of canon law - among crimes against religion. If, on the other hand, falsehood was to be the basis for legal classification, perjury meant a crime against truth, justice or falsification (Syryjczyk, 1991, p. 122). The condition, however, was that the oath be made by a believer. Meanwhile, passive suffrage in the presidential election in the Second Polish Republic did not prescribe any religious denomination for the candidates. Both fundamental acts promoted freedom in this regard and the separation of church from state. The oath of the newly elected president took place before the National Assembly in the Sejm or in the Royal Castle. It was sworn on the constitution, not the Bible (Witkowski, 1987, p. 33). The religious references concerned only the content of the oath and the fact that it was uttered next to a cross. However, this does not change the fact that the legal obligation to take the oath to God could, and in the case of Gabriel Narutowicz did, violate the freedom of conscience and religion, and therefore with the fundamental rights of the individual.

After the political transformation of the late 1980s and early 1990s, the need to distinguish between oath and vow was not recognized. With regard to the president-elect, the word oath was used in legal acts, despite its secular content and form. This meant adopting the understanding of this institution as per legal sciences, according to which an oath is a "solemn, usually public and verbal promise of a particular way of conduct, verbalized in words of officially defined content and sometimes also submitted in a specific form" (Maroń, 2015, p. 52). Religious references of the presidential oath were limited to the optional reference to

${ }_{11}$ The presidential oath prescribed by the Constitution of 23 April, 1935 did not include a vow to the Polish nation. 
God at the end of the formula and to the presence of the cross in the Sejm sessions chamber. Thus, God was no longer the addressee or the witness of the promise, and could be only a helper. Although the authors of the Catechism of the Catholic Church stated that "discretion in calling upon God is allied with a respectful awareness of his presence" (CCC 2153), all the presidents-elects declaring their Catholic faith ended the oath with the words "So help me God."

\section{Conclusion}

The swearing-in ceremony of the President of the Republic of Poland after 1989 features a number of references to the liturgy of the sacraments in the Catholic Church. As with the sacraments, the status of the person who participates in the ceremony is subject to change. Although one becomes the President of the Republic of Poland as a result of electoral victory announced by the National Electoral Commission, which the Supreme Court affirms, without uttering the words of the oath, the victor remains only a president-elect. Thus, swearing-in is a legally regulated public ritual which must be completed in order to formally begin the function. Written in the Constitution, and uttered by the newly elected head of state, the oath has performative value. This means that, analogously to the baptismal formula, pronouncing certain words is an action that causes the assumed effect. However, in order for the performative to be successful, it is also necessary to fulfill the non-verbal conditions, which include the appropriate gestures, proper context and authorized participants. Despite these analogies, as well as despite the fact that it draws on the medieval tradition of enthroning Christian European rulers, the swearing-in of the head of state is now secular. The sacred references were, in this case, limited to the optional formula of an appeal to God as a helper and witness of the oath. This is the only literal remnant of the influence of religion on the most important state ceremony in Poland.

${ }^{12}$ Compare the categorical objection to swearing to heaven, among others in the Gospel according to Matthew (Mt 5:34). The mere requirement to take an oath and the inability to replace it with a vow may, however, give rise to difficulties in the future, resulting from the conflict between the legal norm and conscience (e.g., for people who for whom any swearing is banned for religious reasons; Maroń, 2015, p. 72). 


\section{Bibliography}

\section{Legal acts:}

The Act of January 5, 2011 - Election Code, Journal of Laws 2011, No. 21, item 112 as amended.

The Constitution of the Republic of Poland of April 2, 1997, Journal of Laws 1997, No. 78, item 483 as amended.

Constitutional Act of October 17, 1992 on mutual relations between the legislative and executive power of the Republic of Poland and the local government, Journal of Laws 1992, No. 84, item 426.

Act of September 27, 1990 on the election of the President of the Republic of Poland, Journal of Laws 1990, No. 67, item 398 as amended.

Act of December 29, 1989 amending the Constitution of the Polish People's Republic, Journal of Laws 1989, No. 75, item 444.

Act of April 7, 1989 amending the Constitution of the Polish People's Republic, Journal of Laws 1989, No. 19, item 101.

The Constitution of the Polish People's Republic of July 22, 1952, Journal of Laws 1952, No. 33, item 232.

Constitutional Act of February 19, 1947, Journal of Laws 1947, No. 18, item 71.

The Constitution of the Republic of Poland of April 23, 1935.

The Constitution of the Republic of Poland of March 17, 1921.

\section{Other sources:}

Austin J. L. (1993), Mówienie i poznawanie, Warszawa.

Baszkiewicz J. (1998), Myśl polityczna wieków średnich, Poznań.

Biblia Tysiqclecia. Pismo Święte Starego i Nowego Testamentu (2003), Poznań.

Böckenförde E. W. (2005-2006), Teoria polityki a teologia polityczna. Uwagi na temat ich wzajemnego stosunku, "Teologia Polityczna," no. 3.

Chmaj M. (1996), Sejm ,kontraktowy” w transformacji systemu politycznego Rzeczypospolitej Polskiej, Lublin.

Churska-Nowak K. (2009), Rytuały polityczne w demokracji masowej, Poznań.

Churska-Nowak K., Orylski Ł. (2010), The boundaries between the religious and the secular on the Polish political scene, "Środkowoeuropejskie Studia Polityczne," no. 2.

Eller J. D. (2012), Antropologia kulturowa. Globalne siły, lokalne światy, Kraków.

Filipowicz S. (1998), Mit i spektakl władzy, Warszawa.

Gennep A. van (2006), Obrzędy przejścia. Systematyczne studium ceremonii, Warszawa.

Gierycz M. (2008), Chrześcijaństwo i Unia Europejska. Rola religii w procesie integracji europejskiej, Warszawa-Kraków. 
Gołembski F. (2012), Cywilizacja europejska, Warszawa.

Gołembski F. (2006), Jedność europejska, Warszawa.

Gołembski F. (2008), Kulturowe aspekty integracji europejskiej, Warszawa.

Górecki D. (1997), Wpływ polskich tradycji ustrojowych na współczesne rozwiazania konstytucyjne, in: Konstytucyjne systemy rzqdów, ed. M. Domagała, Warszawa.

Kałuszyńska E. (n.d.), Język a rzeczywistość. Performatywna funkcja języka, Lublin, http://bacon.umcs.lublin.pl/ lukasik/Konferencja\%20(teksty\%20referatow)/ Kaluszynska.pdf, 15.06.2018.

Kantorowicz E. (2007), Dwa ciała króla. Studium ze średniowiecznej teologii politycznej, Warszawa.

Katechizm Kościoła Katolickiego (KKK, 1994 [1992]), Poznań.

Kłoczkowski J. (2004), Europa - chrześcijańskie korzenie, Warszawa.

Kodeks prawa kanonicznego (KPK, 1983).

Konstytucja o Liturgii Świętej (KL, 1963).

Leach E., Greimas A. J. (1989), Rytuat i narracja, Warszawa.

Mała encyklopedia kultury antycznej (1988), ed. Z. Piszczek, Warszawa.

Marini P. (2007), Liturgia i piękno. Nobilis pulchritudo, Pelplin.

Maroń G. (2012a), Instytucja przysięgi prezydenta w polskim porzadku prawnym, "Przegląd Prawa Konstytucyjnego," no. 2.

Maroń G. (2015), Instytucja przysięgi (ślubowania) a poszanowanie wolności sumienia i religii, "Przegląd Prawa Konstytucyjnego," no. 4 (26).

Maroń G. (2012b), Ślubowanie senatorskie w polskim porzqdku prawnym, "Zeszyty Naukowe Uniwersytetu Rzeszowskiego. Seria prawnicza,” no. 74/11.

Mojak R. (1997a), Instytucja Prezydenta RP w świetle nowej Konstytucji, "Państwo i Prawo," no. 11-12.

Mojak R. (1997b), Pozycja ustrojowa i struktura władzy wykonawczej. Problematyka stosunków między prezydentem a rzqdem, in: Ustrój i struktura aparatu państwowego i samorzqdu terytorialnego, ed. W. Skrzydło, Warszawa.

Mojak R. (2000), Władza wykonawcza w Konstytucji RP, in: Ustrój konstytucyjny Rzeczypospolitej Polskiej, Lublin.

Monarchia w średniowieczu (2002), eds. J. Pysiak, A. Pieniądz-Skrzypczak, M. R. Pauk, Warszawa-Kraków.

Nadolski B. (1989), Liturgika, vol. I: Liturgika fundamentalna, Poznań.

Ochmann-Staniszewska S. (1995), Przysięga marszałka poselskiego na sejmach lat 1648-1668, “Czasopismo Prawno-Historyczne," vol. XVVII, 1-2.

Paprocki H. (2007), Bóg i teatr na antypodach..., "Więź," nr 5, electronic version: http://www.wiez.pl/czasopismo/;s,czasopismo_szczegoly,id,525,art,14445, 20.06.2018.

Pietrzak J. (2010), Senat Rzeczypospolitej Polskiej. Tradycja i wspótczesność XV-XXI w., Warszawa. 
Sarnecki P. (1990), Prezydent jako organ czuwajacy nad przestrzeganiem Konstytucji, "Państwo i Prawo," no. 11.

Segalen M. (2009), Obrzędy i rytuały współczesne, Warszawa.

Skrzydło W. (1996), Przemiany polityczno-ustrojowe $w$ Polsce na przełomie lat osiemdziesiatych $i$ dziewięćdziesiatych, in: Prawo konstytucyjne, ed. W. Skrzydło, Lublin.

Słownik języka polskiego (2018), electronic version: https://sjp.pwn.pl/, 14.06.2018.

Słownik języka polskiego (1984), ed. M. Szymczak, Warszawa, vol. 2, 3.

Stownik grecko-polski (2015), ed. O. Jurewicz, Warszawa.

Sokolewicz W. (1989), Kwietniowa zmiana Konstytucji, "Państwo i Prawo," no. 6.

Strzelczyk J. (2007), Cis Oceanum et Ultra. Ernst Kantorowicz i jego dzieło, in: Kantorowicz E., ibid.

Syryjczyk J. (1991), Krzywoprzysięstwo w systematyce kanonicznego prawa karnego, "Prawo Kanoniczne. Kwartalnik prawno-historyczny," no. 34/1-2.

Towarek P. (2008), Średniowieczny dramat liturgiczny i jego oddziaływanie na współczesna liturgię Kościoła, "Studia Elbląskie," no. 9.

Turner V. W. (2010), Proces rytualny. Struktura i antystruktura, Warszawa.

Urbańczyk P. (2000), Władza i polityka we wczesnym średniowieczu, Wrocław.

Witkowski Z. (1987), Prezydent Rzeczypospolitej Polskiej 1921-1935, WarszawaPoznań-Toruń.

Wolański A. (2005), Dramat liturgiczny w średniowieczu, Gdańsk.

\section{Liturgiczne odniesienia zaprzysiężenia Prezydenta Rzeczypospolitej Polskiej po 1989 roku}

\section{Streszczenie}

Celem tekstu jest analiza wzajemnych powiązań między liturgią sakramentów a najważniejszą ceremonią państwową Trzeciej Rzeczypospolitej, którą jest zaprzysiężenie głowy państwa. Ma ono charakter świecki, choć jego antecedencji należy upatrywać w religijnych aspektach intronizacji władców europejskich w wiekach średnich. Te odniesienia czynią z zaprzysiężenia przedmiot badań łączący teologię i politologię. Prowokują one pytania o związki między religijnymi wyobrażeniami danej wspólnoty narodowej a jej organizacją polityczną, wyrażające się w ceremoniach państwowych. Prezydent Rzeczypospolitej Polskiej staje się nim w wyniku zwycięstwa wyborczego, ogłoszonego przez Państwową Komisję Wyborczą, którego ważność stwierdza Sąd Najwyższy. Do czasu wypowiedzenia słów roty, nowo wybrany prezydent pozostaje jednak jedynie elektem. Zaprzysiężenie jest zatem uregulowanym prawem rytuałem publicznym, którego należy dopełnić, aby formalnie rozpocząć wykonywanie funkcji. Zapisana w Konstytucji i wypowiedziana przez nowo wybraną głowę państwa przysięga ma tym samym walor performatywny, analogicznie do 
formuł liturgicznych. Ponadto zawiera ona fakultatywną formułę wezwania Boga na świadka złożonej przysięgi. Rota prezydencka pozostaje zatem uwarunkowanym historycznie świadectwem odwołania się do sfery sacrum przed władzę publiczną.

Słowa kluczowe: ceremoniał, zaprzysiężenie głowy państwa, liturgia, rytuał 